\title{
格子桁 の最小重量設 計* MINIMUM WEIGHT DESIGN OF GRILLAGE GIRDER
}

\section{1. 緒論}

塑性解析に基づいた骨組構造物の最小重量設計問題の 研究は 1953 年の J. Foulkes の論文 ${ }^{1,2)}$ によって注目 され，初期の頃は主として試算によりこの問題の解を見 い出すよう努力されたが，1957 年頃より H.J. Greenberg, W. Prager の極限強度解析に関する下界定理を 态用して極值問題として取り扱ら方法が研究され, トラ ス, 連続枌, ラーメンに対し線型計画法の手法を利用し

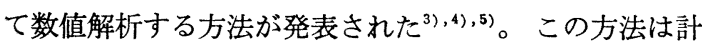
算自体は非常に繁雑であるが，組織的，かつ機械的であ るため電子計算機の発達している今日, 非常に有効な方 法といえる。一方, 格子桁の最小重量設計に関しては, J. Heymann ${ }^{6}$, 米沢 ${ }^{7}$ の研究があるが, これらはやはり 試算による解析法であり, 簡単な構造とか特殊の形状の ものには有力であるが一般性に乏しいうらみがある。

本研究は集中荷重および分布荷重, またはそれらの組 み合わせ荷重が変動する格子桁の最小重量設計問題を数 理計画法の問題に置き換えて解析したものである。一般 に分布荷重が作用すれば, 曲げモーメントの極值をとる ことが可能な点は無数に存在し, 降伏条件式を犯さない ことを意味する制約条件式は考えている骨組みの有限個 の位置に作用する曲げモーメントの線型不等式として表 わすことができない。また一方, 格子桁のように曲げモ 一メント以外にねじりモーメントも関係すれば，降伏条 件式は応力の非線型な式となり，それゆえ制約条件式は 非線型となる。したがって，分布荷重を受ける格子桁の 問題は従来よく行なわれているよ5に重量関数を線型化 したとしても線型問題にはならず, 数理計画の問題とし て，解析するには非線型計画法の手法を用いなければな

\footnotetext{
* 第 25 回土木学会年次学術講演会 $(1970-10)$ にて一部発表

** 正会員 大阪市立大学教授 工学部土木工学科

*** 正会員 大阪市立大学輩師 工学部土木工学科
}

\author{
倉 田 宗 章**・園田 恵一 郎*** \\ By Muneaki Kurata and Keiichiro Sonoda
}

らない。本研究においては非線型制約条件式の凸性を考 慮し, 格子桁の問題を凸計画の問題として取り扱い, J.E. Kelley の Cutting Plane Method ${ }^{8)}$ を利用した計 算方法を提示した。また計算例として橋梁構造に多く見 られる格子桁をとり上げ, 集中荷重, 等分布荷重, 移動 線荷重に対する最小重量設計を試みた。

\section{2. 問題の設定}

格子点間の部材は等断面を持つものと仮定し, $n$ 個の 部材のそれぞれの全塑性曲げモーメントを求むべき設計 変数として $\boldsymbol{x}=\left(x_{1}, x_{2}, x_{3}, \cdots, x_{n}\right)$ で定義し, 各部材 における全塑性ねじりモーメントの全塑性曲げモーメン トに対する比を $\boldsymbol{\beta}=\left(\beta_{1}, \beta_{2}, \beta_{3}, \cdots, \beta_{n}\right)$ とし, 格子点上 に作用する曲げモーメントおよびねじりモーメントを $\boldsymbol{y}$ $=\left(y_{1}, y_{2}, y_{3}, \cdots, y_{3 n}\right)$ とする。一般に重量関数 $W$ は 各部材の長さと断面積との積和によって, また断面積は その部材の塑性断面係数の関数として表わすことができ るから，ここで考えている問題は,

$$
\begin{aligned}
& g_{i}(\boldsymbol{y})=\mu P_{\boldsymbol{i}}(i=1,2,3, \cdots, k) \cdots \cdots \\
& f_{\boldsymbol{i}}(\boldsymbol{y}, \boldsymbol{x}, \boldsymbol{\beta}) \leq 0(i=1,2,3, \cdots, r)
\end{aligned}
$$

の下で重量関数 $W(\boldsymbol{l}, \boldsymbol{x})$ を最小にする $\boldsymbol{x}$ を求めるこ とに帰着する。ここに $\boldsymbol{l}=\left(l_{1}, l_{2}, l_{3}, \cdots, l_{n}\right)$ であり部材長 を表わし， $P_{i}$ は設計荷重, $\mu$ は荷重係数 (load factor), $k$ は独立なつりあい条件式の数, $r$ はモーメントの極值 をとることの可能な位置の数を示す。また式 (2) は降伏 条件式と荷重の分布状態により定まる関係式で, 考えて いる格子桁のいかなる場所においても降伏条件式を犯さ ないことを意味している。

\section{(1) 重量関数}

I 型断面と箱型断面を対象とし, 日本溶接協会塑性設 計研究委員会編鋼構造物塑性設計規準（案）にて許され る最大幅厚比と最大ウエブ高さを持つ断面に対して, 同 


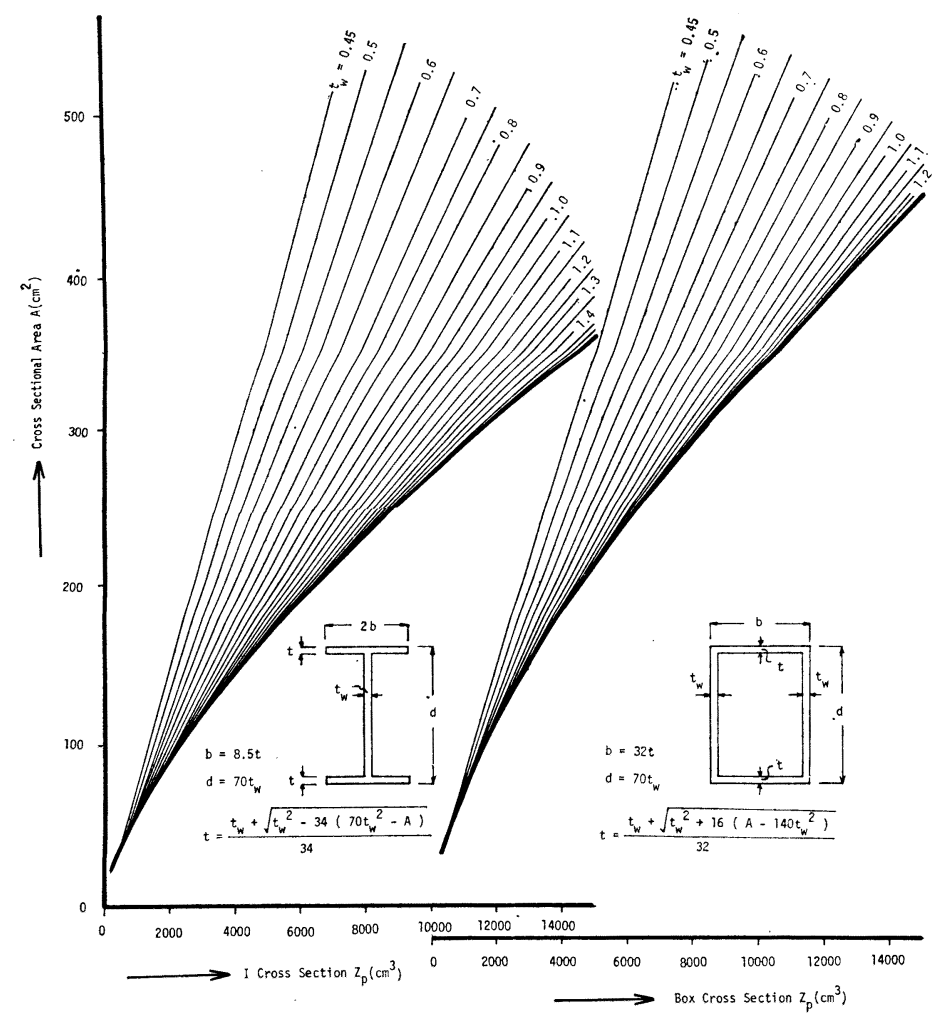

Fig. 1

じ塑性断面係数を持つ断面の中で面積を最小にするもの を選び出し, 断面積 $A\left(\mathrm{~cm}^{2}\right)$ と塑性断面係数 $Z_{p}\left(\mathrm{~cm}^{3}\right)$ との間の関係を示せば， Fig. 1 の太線のようになる。 この曲線は三次曲線で精度良く表わすことができるが, 実際の計算に際しては次のようれ折線近似を用いる方が 都合が良い。

I 型断面に対しては

$$
\left.\begin{array}{lr}
A=0.0428 Z_{p}+15.7 & 100 \leq Z_{p} \leq 1500, \\
A=0.0273 Z_{p}+39.0 & 1500 \leq Z_{p} \leq 4500, \\
A=0.0203 Z_{p}+71.1 & 4500 \leq Z_{p} \leq 9500 .
\end{array}\right\}
$$

箱型断面に対しては

$$
\begin{aligned}
& A=0.0462 Z_{p}+28.5 \\
& A=0.0317 Z_{p}+57.6 \\
& 400 \leq Z_{p} \leq 2000, \\
& 2000 \leq Z_{p} \leq 5500 \text {, } \\
& A=0.0242 Z_{p}+99.0 \\
& 5500 \leq Z_{p} \leq 10000 \text {, } \\
& A=0.0214 Z_{p}+127 \text {. }
\end{aligned}
$$

次に上記の最小断面積を与える断面形において全塑性 曲げモーメントに対する全塑性ねじりモーメントの比 $\beta$ を計算すれば， I 型断面では $0.0126 \sim 0.0138$, 箱型断 面では 0.467 ～ 0.549 であり，いずれもほぼ一定值を示 している (付録 1 参照)。それゆえ特に $\beta$ を設計変数と して扱らほどの必要性はないものと思われる。

\section{（2）応力つりあい条件式}

格子桁の応力つりあい条件式は格子点 の断面に作用する曲げモーメントおよび ねじりモーメントと荷重との間の関係式 として表わすことができる。すなわち，

Fig. 2 に示す任意の格子点 $i$ に関して つりあい条件式をつくれば,

$$
\begin{gathered}
\frac{1}{\Lambda_{i h}}\left(M_{i h}-M_{h i}\right) \\
\quad+\frac{1}{\Lambda_{i m}}\left(M_{i m}-M_{m i}\right) \\
\quad+\frac{1}{\Lambda_{i j}}\left(M_{i j}-M_{j i}\right) \\
\quad+\frac{1}{\Lambda_{i n}}\left(M_{i n}-M_{n i}\right) \\
=p_{i}+\frac{1}{2}\left(q_{i h} \Lambda_{i h}+q_{i m} \Lambda_{i m}\right. \\
\left.\quad+q_{i j} \Lambda_{i j}+q_{i n} \Lambda_{i n}\right) \cdots \cdots \cdots \\
M_{i h}-M_{i j}+T_{i m}-T_{i n}=0 \cdots \\
M_{i m}-M_{i n}+T_{i h}-T_{i j}=0 \cdots
\end{gathered}
$$

ここに，M は格子点に作用する曲げ モーメント, $T$ はねじりモーメント, $A$ は部材長, $q$ は等分布荷重強度, $p$ は集 中荷重強度を表わし, 二重添字は着目す る部材を表わす。後に示す凸計画法の計 算手法を適用するに際して, 変数は非負であるとして取 り扱う方が都合がよいので，モーメント変数は次のよう に変換する。

$$
\left.\begin{array}{rlrl}
M_{i h}{ }^{\prime} & =M_{i h}+X_{i h}, & & M_{i m}{ }^{\prime}=M_{i m}+X_{i m} \\
T_{i h}{ }^{\prime} & =T_{i h}+\beta_{i h} X_{i h}, & T_{i m}{ }^{\prime}=T_{i m}+\beta_{i m} X_{i m}
\end{array}\right\}
$$

ここに, $X_{i h}, X_{i m}, \cdots$ は部材 $i h, i m, \cdots$ の全塑性曲 げモーメント, $\beta_{i h}, \beta_{i m}, \cdots$ は部材 $i h, i m, \cdots$ における 全塑性ねじりモーメントの全塑性曲げモーメントに対す る比を表わす。

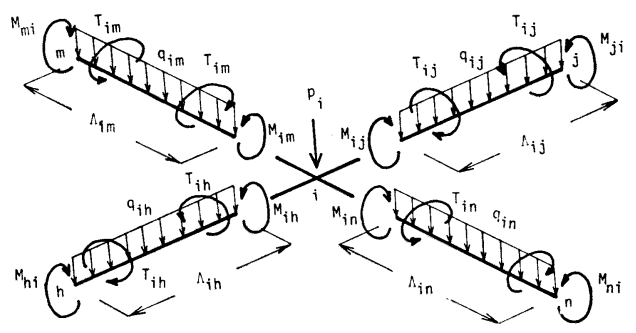

Fig. 2

次に支持端における条件を考える。端横桁のない単純 支持端に対しては曲げモーメントをゼロ，さらにこの支 持端がねじりにも自由であるならばねじりモーメントを もゼロにおけばよく, 剛に結合された端横桁をもった場 
合は単純支持端に対して式 (4.2) および式 (4.3) に相 当する条件式を用いればよい。したがって，すべての格 子点および支持端に対して式をつくれば，つりあい条件 式全体は次のようなマトリッス形式で表わすことができ る。

$$
\left.\underset{k \times 3 n}{\boldsymbol{A}}][\underset{3 n \times 1}{\{\boldsymbol{y}}\}-\underset{3 n \times n}{[\boldsymbol{T}}]_{n \times 1}\{\boldsymbol{x}\}\right]=\{\underset{k \times 1}{\boldsymbol{P}}\}
$$

ここに，[A]は構造の幾何学的形状により定まるマト リックス, $\{\boldsymbol{y}\}$ はモーメント変数 $M_{i h^{\prime}}, T_{i h^{\prime}} M_{i m^{\prime}}$, $T_{i m}{ }^{\prime}, \cdots$ よりなる列マトリックス, $[\boldsymbol{T}]$ は式 (5) の非 負なるモーメント変数の導入によって必要となる変換す るマトリックス, $\{\boldsymbol{x}\}$ は各部材の全塑性曲げモーメント $X_{i h}, X_{i m}, \cdots$ を表わす列マトリックスで問題の求むべき 設計変数であり, $\{\boldsymbol{P}\}$ は荷重項を表わす列マトリック スである。

上述のつりあい条件式は固定荷重に対して誘導された が, 変動荷重が作用する場合にも同様に導くことがで き, 式 (6) は次のように変わる。

$$
\left.\left.\underset{k \times 3 n}{\boldsymbol{A}}][\underset{3 n \times l}{[\boldsymbol{y}}]-\underset{3 n \times n}{[\boldsymbol{T}]} \underset{n \times 1}{\{\boldsymbol{x}}\} \underset{1 \times l}{\{\boldsymbol{I}\}^{\prime}}\right]=\underset{k \times l}{[\boldsymbol{P}}\right]
$$

ここに，[A], $[\boldsymbol{T}],\{\boldsymbol{x}\}$ は式 (6) のそれらと同一で あり, l は荷重の変動する回数を示し, $[\boldsymbol{y}]$ はそれぞれ の変動荷重群に対応するモーメント変数, $[\boldsymbol{P}]$ は荷重 項, $\{\boldsymbol{I}\}$ はすべての要素が 1 なる列マトリックスで右肩 に付したダッシュはその転置行マトリックスなることを 意味する。

\section{（3）降伏条件式}

集中荷重のみが格子点上に作用した場合は，曲げモー メントの極值は必ず格子点において起こるから，降伏条 件式を犯さない条件は格子点上においてのみつくれば十 分である。いま曲げとねじりを同時に受ける桁の降伏条 件式を次のように仮定すれば,

$$
\left(\frac{M}{M_{0}}\right)^{2}+\left(\frac{T}{T_{0}}\right)^{2}=1
$$

ここに $M_{0}, T_{0}$ は全塑性曲げおよびねじりモーメント を示す, Fig. 2 の格子点において降伏条件式を犯さな い条件は次のようになる。

$$
\left.\begin{array}{l}
\left(M_{i h^{\prime}}-X_{i h}\right)^{2}+\frac{1}{\beta_{i h}{ }^{2}}\left(T_{i h^{\prime}}-\beta_{i h} X_{i h}\right)^{2} \leq X_{i h^{2}} \\
\left(M_{i j^{\prime}}{ }^{\prime} X_{i j}\right)^{2}+\frac{1}{\beta_{i j^{2}}}\left(T_{i j^{\prime}}-\beta_{i j} X_{i j}\right)^{2} \leq X_{i j^{2}} \\
\left(M_{i m^{\prime}}-X_{i m}\right)^{2}+\frac{1}{\beta_{i m^{2}}}\left(T_{i m^{\prime}}-\beta_{i m} X_{i m}\right)^{2} \leq X_{i m^{2}} \\
\left(M_{i n}{ }^{\prime}-X_{i n}\right)^{2}+\frac{1}{\beta_{i n}{ }^{2}}\left(T_{i n}{ }^{\prime}-\beta_{i n} X_{i n}\right)^{2} \leq X_{i n}{ }^{2}
\end{array}\right\}
$$

ここで考えている最小重量設計の問題においては, 変 数は格子点に働く曲げおよびねじりモーメントと各部材 の全塑性曲げモーメントであり, 全塑性曲げモーメント
に対する全塑性ねじりモーメントの比 $\beta$ はあらかじめ与 えられた定数と考える。次に式 (9) の不等式を満足する 領城は $M_{i h^{\prime}}, T_{i h^{\prime}}{ }^{\prime} X_{i h}$ 座標空間内の点 $(0,0,0)$ にお いていわゆる凸性を失うので, $X_{i h} \geq 0, X_{i j} \geq 0, \cdots$ を 考慮して式 (9) を次のように書き変える。

$$
\begin{aligned}
& \sqrt{\left(M_{i h^{\prime}}-X_{i h}\right)^{2}+\frac{1}{\beta_{i h}{ }^{2}}\left(T_{i h^{\prime}}-\beta_{i h} X_{i h}\right)^{2}}-X_{i h} \leq 0 \text {, }
\end{aligned}
$$

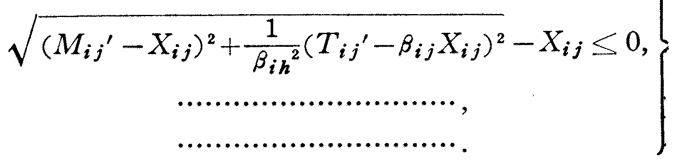

式（10）を満足する領域は凸性を有するので，この種 の制約条件式をもつ問題は J.E. Kelley の Cutting Plane Method ${ }^{8)}$ を用いて解くことができる。この方法 は非線型制約条件式を Cutting Planes を用いて線型化 し，線型計画の問題を繰り返し計算することによって最 適解を求める方法である。この方法を用いて式 (10)の 第 1 式を満足しない任意の点 $\left(t_{1}, t_{2}, t_{3}\right)$ に対する Cutting Plane を求め, これによる線型制約条件式を求む れば (付録 2 参照)，

$$
\begin{aligned}
& \left(t_{1}-t_{3}\right) M_{i h^{\prime}}+\frac{t_{2}-\beta_{i h} t_{3}}{\beta_{i h^{2}}{ }^{2}} T_{i h^{\prime}} \\
& -\left\{\sqrt{\left(t_{1}-t_{3}\right)^{2}+\frac{1}{\beta_{i h}^{2}}\left(t_{2}-\beta_{i h} t_{3}\right)^{2}}+t_{1}-t_{3}\right. \\
& \left.+\frac{t_{2}-\beta_{i h} t_{3}}{\beta_{i h}}\right\} X_{i h} \leq 0
\end{aligned}
$$

格子点 $i$ に対しては同様な他の三つの 不等式が得ら れ，格子桁全体では $2 n l$ 個の不等式ができる。

次に, 格子点間に等分布荷重が作用した場合には, 格 間で降伏条件を犯さない条件を付加しなければならな い。このためには, 格間ではねじりモーメントは一定で あるので, 曲げモーメントの正の最大值をとる点におい て式 (10) と同等な不等式を満足させれば十分である。

いま Fig. 2 の部材 $i h$ を例にとって考えるならば,

$$
\begin{aligned}
& M_{i h^{\prime}}-M_{h i^{\prime}} \geq \frac{q_{i h} \Lambda_{i h^{2}}}{2}, \text { または } \\
& M_{i h^{\prime}}-M_{h i^{\prime}} \leq-\frac{q_{i h} \Lambda_{i h^{2}}}{2}
\end{aligned}
$$

なら, 曲げモーメントの極值は端点 $i$ または $h$ におこ り, 式 (10) 以外の新たな制約条件式は必要でない, し かし

$$
-\frac{q_{i h} \Lambda_{i h}{ }^{2}}{2}<M_{i h^{\prime}}-M_{h i}{ }^{\prime}<\frac{q_{i h} \Lambda_{i h^{2}}}{2}
$$

なら, 曲げモーメントの正の極值は格間内で起こり, 次 の新しい条件式を付加しなければならない。

$$
\begin{aligned}
& \sqrt{\left(M_{\max }^{\prime}-X_{i h}\right)^{2}+\frac{1}{\beta_{i h}{ }^{2}}\left(T_{i h^{\prime}}-\beta_{i h} X_{i h}\right)^{2}} \\
& -X_{i h} \leq 0
\end{aligned}
$$


ここに

$$
\begin{aligned}
M_{\max }^{\prime}= & \frac{q_{i h} \Lambda_{i h^{2}}}{8}+\frac{1}{2}\left(M_{i h^{\prime}}+M_{h i^{\prime}}\right) \\
& +\frac{1}{2 q_{i h^{1} \Lambda_{i h^{2}}{ }^{2}}}\left(M_{i h^{\prime}}-M_{h i^{\prime}}\right)^{2}
\end{aligned}
$$

ただし上式は $M_{\text {max }}^{\prime} \geq X_{i h}$ の時のみ適用される式で ある。

前と同様, $M_{i{ }^{\prime}}{ }^{\prime}, M_{h i}{ }^{\prime}, T_{i h^{\prime}}{ }^{\prime}, X_{i h}$ 座標空間内で式 （12）を満足しない任意の点 $\left(t_{1}, t_{1}{ }^{\prime}, t_{2}, t_{3}\right)$ に対して Cutting Plane による制約条件式をつくれば，次のよ らになる (付録 2 参照)。

$$
\begin{aligned}
& \left\{1+\frac{2}{q_{i h \Lambda_{i h}{ }^{2}}}\left(t_{1}-t_{1}{ }^{\prime}\right)\right\} M_{i h^{\prime}}+\left\{1-\frac{2}{q_{i h} \Lambda_{i h^{2}}}\right. \\
& \text { - } \left.\left(t_{1}-t_{1}{ }^{\prime}\right)\right\} M_{h i}{ }^{\prime}+\frac{2\left(t_{2}-\beta_{i h} t_{3}\right)}{\beta_{i h^{2}\left(t_{0}-t_{3}\right)}} T_{i h^{\prime}}-\frac{2}{t_{0}-t_{3}} \\
& \cdot\left\{t_{0}+\frac{t_{2}}{\beta_{i h}}-2 t_{3}+\sqrt{\left(t_{0}-t_{3}\right)^{2}+\frac{1}{\beta_{i h}{ }^{2}}\left(t_{2}-\beta_{i h} t_{3}\right)^{2}}\right\} \\
& \cdot X_{i h} \leq-\frac{q_{i h} \Lambda_{i h^{2}}}{4}+\frac{1}{q_{i h} \Lambda_{i h^{2}}}\left(t_{1}-t_{1}{ }^{\prime}\right)^{2} \cdot \\
& \text { ここに } \\
& t_{0}=\frac{q_{i h} \Lambda_{i h^{2}}}{8}+\frac{1}{2}\left(t_{1}+t_{1}{ }^{\prime}\right)+\frac{1}{2 q_{i h} \Lambda_{i h}{ }^{2}}\left(t_{1}-t_{1}{ }^{\prime}\right)^{2} \geq t_{3} .
\end{aligned}
$$

\section{3. 凸計画の問題としての計算方法}

前節で示したように部材の断面積と塑性断面係数の間 の関係式を線型化すれば，重量関数は次のように表わす ことができる。

$$
W(\boldsymbol{x})=c_{0}+\{\boldsymbol{c}\}^{\prime}\{\boldsymbol{x}\}
$$

ここに $c_{0}$ は正の定数，\{c\} は式 (3.1),(3.2) の係数 と部材長の積からなる列マトリックスである。次に式 (10)，式（12）の制約条件式は線型でないので，Cutting Plane Method により線型化し，解が十分収束す るまで繰り返し計算する。すなわち，最初の計算は式 (10)，式（12）を満足する領域を包含するような近似許 容領域を次のように考え,

$$
[\mathbf{0}] \leq[\boldsymbol{y}] \leq 2[\boldsymbol{T}]\{\boldsymbol{x}\}\{\boldsymbol{I}\}^{\prime}
$$

ここに $[\boldsymbol{T}],\{\boldsymbol{I}\}^{\prime}$ は式 (7) のものと同一である。こ の制約条件式と応力つりあい条件式（7）および $\{\boldsymbol{x}\} \geq$ $\{0\}$ を満足する中で $W(\boldsymbol{x})=c_{0}+\{\boldsymbol{c}\}^{\prime}\{\boldsymbol{x}\}$ を最小にする ような $[\boldsymbol{y}],\{\boldsymbol{x}\}$ を求める。これは線型計画の問題であ り，シンプレックス法 ${ }^{9), 10)}$ によって解くことが可能であ るが，このままでは制約条件式が多く，しかも以後の繰 り返し計算によってますますその数が増加するから，実 際の計算に便利なように問題を書き変える。すなわち， 式 (7) の係数行列を次のように分割する。

$$
\left[\boldsymbol{A}_{1} ; \boldsymbol{A}_{2}\right]\left\{\left[\begin{array}{c}
\underline{\boldsymbol{y}}_{1} \\
\boldsymbol{y}_{2}
\end{array}\right]-\left[\begin{array}{c}
\boldsymbol{T}_{1} \\
\boldsymbol{T}_{2}
\end{array}\right]\{\boldsymbol{x}\}\{\boldsymbol{I}\}^{\prime}\right\}=[\boldsymbol{P}]
$$

ここに $\boldsymbol{A}_{\mathbf{1}}$ は $k \times k, \boldsymbol{A}_{\mathbf{2}}$ は $k \times(3 n-k), \boldsymbol{y}_{\mathbf{1}}$ は $k \times l$, $\boldsymbol{y}_{\mathbf{2}}$ は $(3 n-k) \times l, \boldsymbol{T}_{\mathbf{1}}$ は $k \times n, \boldsymbol{T}_{\mathbf{2}}$ は $(3 n-k) \times n$ の 各マトリックスである。よって,

$$
\boldsymbol{y}_{1}=\boldsymbol{A}_{1}^{-1} P-A_{1}^{-1} A_{2} y_{2}+\left\{T_{1}+A_{1}^{-1} A_{2} T_{2}\right\}\{x\}\{I\}^{\prime},
$$

ただし $\left|\boldsymbol{A}_{1}\right| \neq 0$, となり，

$$
\begin{aligned}
{[\boldsymbol{y}] } & =\left\{\begin{array}{c}
\boldsymbol{y}_{1} \\
\boldsymbol{y}_{2}
\end{array}\right\}=\left[\begin{array}{c}
\boldsymbol{A}_{1}^{-1} \\
\boldsymbol{0}
\end{array}\right][\boldsymbol{P}]+\left[\begin{array}{c}
-\boldsymbol{A}_{1}^{-1} \boldsymbol{A}_{2} \\
\boldsymbol{I}
\end{array}\right]\left[\boldsymbol{y}_{2}\right] \\
& +\left[\begin{array}{c}
\boldsymbol{T}_{1}+\boldsymbol{A}_{1}^{-1} \boldsymbol{A}_{2} \boldsymbol{T}_{2} \\
\mathbf{0}
\end{array}\right]\{\boldsymbol{x}\}\{\boldsymbol{I}\}^{\prime} \cdots \cdots \cdots \cdots \cdots
\end{aligned}
$$

となる。したがって前述の線型計画の問題は次のように なる。

Minimum $\left(c_{0}+\{\boldsymbol{c}\}^{\prime}\{\boldsymbol{x}\}\right)$,

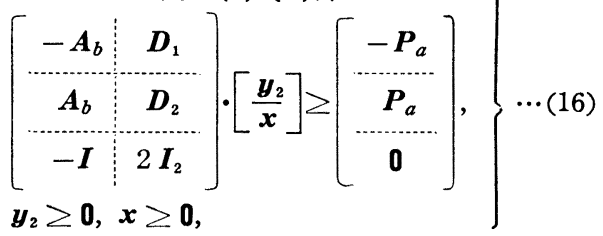

ここに $A_{b}=A_{1}{ }^{-1} A_{2}, P_{a}=A_{1}^{-1} P, x=\{x\}\{I\}^{\prime}, D_{1}=$ $T_{1}+A_{b} T_{2}, \quad D_{2}=T_{1}-A_{b} T_{2}, I$ は単位マトリックス, 0 はゼロマトリックスである。

式 (16) の問題は線型計画法の標準形の裏の問題にな っているので，双対法 ${ }^{9,10)}$ により表の問題に変換すれ ば,

Maximum $\left(c_{0}+\left[-\boldsymbol{P}_{\mathbf{1}}{ }^{\prime}, \boldsymbol{P}^{\prime},\{\mathbf{0}\}^{\prime},-\boldsymbol{P}_{\mathbf{2}}{ }^{\prime}, \boldsymbol{P}_{2}{ }^{\prime}\right.\right.$ $\left.\left.\{0\}^{\prime}, \cdots,-\boldsymbol{P}_{l^{\prime}}, \boldsymbol{P}_{l^{\prime}},\{\mathbf{0}\}^{\prime}\right] \cdot\{\boldsymbol{v}\}\right)$,

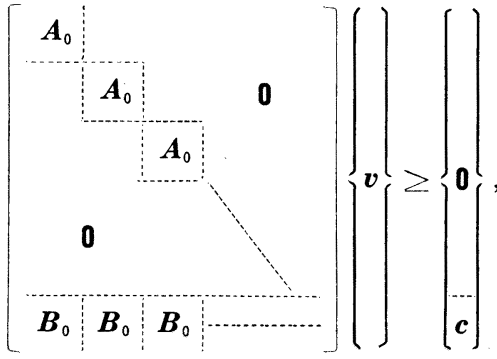

$\{\boldsymbol{v}\} \geq\{\mathbf{0}\}$,

ここに $\boldsymbol{A}_{0}=\left[-\boldsymbol{A}_{\boldsymbol{b}^{\prime}} \boldsymbol{A}_{\boldsymbol{b}}^{\prime}:-\boldsymbol{I}\right], \boldsymbol{B}_{0}=\left[\boldsymbol{D}_{1}^{\prime}: \boldsymbol{D}_{2}^{\prime}: 2 \boldsymbol{T}_{2}{ }^{\prime}\right], \boldsymbol{P}_{\boldsymbol{i}}$ $(i=1,2,3, \cdots, l)$ は $\boldsymbol{P}_{\boldsymbol{a}}$ の第 $i$ 列を示し, 各行列の右 肩に付したダッシュは転置マトリックスなることを意味 する。

式 (17) の線型計画の問題は普通のシンプレックス法 にて解けるが，後の繰り返し計算の関係上改訂シンプレ ックス法 ${ }^{9), 10)}$ を用いる方が都合が良い。こうしてこの問 題の最適解，すなわち, 式 (14) の近似許容領域に対す る解 $\boldsymbol{y}_{2}{ }^{1},\{\boldsymbol{x}\}^{1}$ が得られ，その結果式 (15) より $\boldsymbol{y}_{1}{ }^{1}$ も 求まる。これらの結果を式 (10) および式 (12) の左辺 に代入し，0より大なる值を与えるものについて式(11) および式 (13) の Cutting Plane による新しい制約条 
件式をつくる。

新しい制約条件式を追加すれば，その数だけ式 (17) の $\{\boldsymbol{v}\}$ の係数行列の列の数が増加するが行の数は変化 しないので, 改訂シンプレックス法にて容易に第二近似 解 $\boldsymbol{y}_{2}{ }^{2},\{\boldsymbol{x}\}^{2}$ そして $\boldsymbol{y}_{1}{ }^{2}$ が求められる。以下同様な繰 り返し計算を式 (10), 式 (12) の不等式をすべて許容誤 差の範囲内で満足するまで続ける。なお電子計算機を用 いた実際の計算においては, 第 2 回目以後の繰り返し計 算によって追加される $\{\boldsymbol{v}\}$ の係数行列は第 2 回目の際 の相当する場所に代入することができ，繰り返し数が増 加しても電子計算機の記憶場所を増加させる必要がな い。

以上の計算手順をフローチャートによって説明すれば Fig. 3 のごとくなる。

\section{4. 計 算 例}

\section{(1) 正方形格子桁}

Fig. 4 亿示す単純支持端（ただしねじりには抵抗す る）を持つ正方形格子桁が等分布荷重を受けた場合を例 にとり, 最小重量を与えるときの各部材の大きさを計算 した。部材数は全部で 24 であるが, 対称性を考虑して

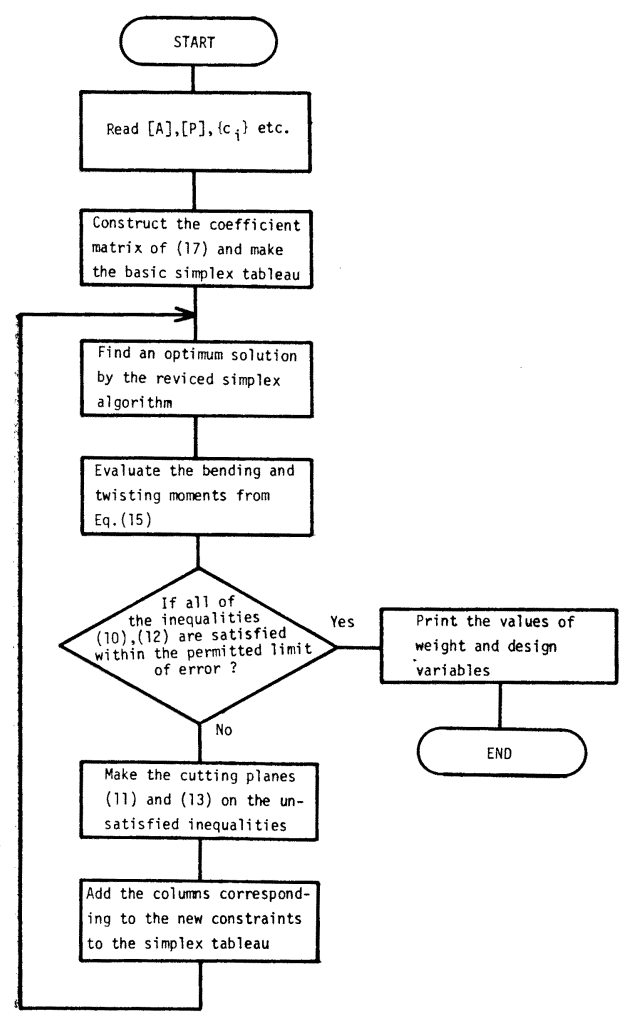

Fig. 3
独立な設計変数を図に示すように 4 個とした。ここでは 正方形格子析の一般的性質を調べることを目的とするた め重量関数は簡単化して, $W(\boldsymbol{x})=c_{0}+4 a\left(X_{1}+2 X_{2}+\right.$ $\left.X_{3}+2 X_{4}\right)$, ここに $c_{0}$ は任意の正の定数, とした。数 値計算結果は Table 1 に示す。当然のことながら部材 のねじり抵抗が増加すればするほど重量は減少し, しか も最適部材の大きさがその比においてかなり変化してい ることがわかる。

次に, 繰り返し計算における解の収束の様子を Table 2 に示す。ここにおける結果は Table 1 の $\beta=0.7$ の 場合に対するものであり， $\delta_{1}$ は各繰り返し段階において 得られた解を式 (11) の不等式群の左辺に代入すること により得られた值の最大值を示し， $\delta_{2}$ は式 (13) の不等 式群に対する最大值を示す。これらの值は解の収束の状 態を表わす量であり, 完全にゼロになれば求むべき解に 到達したことを意味する。ここでは $\delta_{1}$ および $\delta_{2}$ がと もに 5/100000 以下になったとき計算を止めており，14 回の計算で終っている。この結果が示すようにこの程度 の繰り返し回数で重量の值は十分収束しているが, 設計 変数の值はまだかなり変動している。理論的には繰り返 し回数をもっと増加すれば設計変数の值も十分に収束す るはずであるが，実際の計算においては数值計算上の誤

Table 1 Minimum weight design for the square grillage girder shown in Fig. 4

\begin{tabular}{|c|c|c|c|c|c|}
\hline \multirow{2}{*}{$\beta=T_{0} / M_{0}$} & \multicolumn{4}{|c|}{ Design Variables $\left(\times \mathrm{qa}^{2} / 2\right)$} & \multirow{2}{*}{$\begin{array}{l}\text { Weight } \\
W-c_{0} \\
\left(\times 2 q a^{3}\right)\end{array}$} \\
\hline & $X_{1}$ & $X_{2}$ & $X_{3}$ & $X_{4}$ & \\
\hline 0.1 & 7.97346 & 1.00204 & 6.97464 & 1.01881 & 18.98980 \\
\hline 0.2 & 7.92819 & 0.99233 & 6.92964 & 1.05804 & 18.95857 \\
\hline 0.3 & 7.79246 & 1.00157 & 6.79581 & 1.15600 & 18.90341 \\
\hline 0.4 & 7.68577 & 0.96471 & 6.68316 & 1.26026 & 18.81888 \\
\hline 0.5 & 7.47023 & 0.91332 & 6.46452 & 1.46724 & 18.69587 \\
\hline 0.6 & 7.17328 & 0.81470 & 6.17837 & 1.76938 & 18.51980 \\
\hline 0.7 & 6.85346 & 0.58030 & 5.85107 & 2.19965 & 18.26443 \\
\hline 0.8 & 6.32930 & 0.17047 & 5.33536 & 2.93877 & 17.88313 \\
\hline 0.9 & 5.75191 & 0.15414 & 4.78910 & 3.29118 & 17.43164 \\
\hline 1.0 & 5.13839 & 0.24237 & 4.25962 & 3.56682 & 17.01639 \\
\hline 1.15 & 4.04372 & 0.43134 & 3.46342 & 4.03057 & 16.43095 \\
\hline
\end{tabular}

Table 2 Convergency of solution

\begin{tabular}{|c|c|c|c|c|c|c|c|}
\hline \multirow{2}{*}{$\begin{array}{c}\text { Number } \\
\text { of } \\
\text { iteration }\end{array}$} & \multicolumn{4}{|c|}{ Design Variables } & \multirow{2}{*}{$\left|\begin{array}{c}\text { Weight } \\
W-c_{0} \\
\left(\times 2 \mathrm{qa}^{3}\right)\end{array}\right|$} & \multirow{2}{*}{1} & \multirow{2}{*}{$\delta_{2}$} \\
\hline & $X_{1}$ & $X_{2}$ & $X_{3}$ & 4 & & & \\
\hline 0 & 6.4941 & 9 & 00 & 2.0 & \multicolumn{3}{|c|}{$16.2000 \mid 0 . 8 2 8 4 2 5 \longdiv { 0 . 3 4 5 7 0 4 }$} \\
\hline 1 & & & & & \multicolumn{3}{|c|}{$17.84020 .164784 \mid 0.250367$} \\
\hline 2 & & & & & \multicolumn{3}{|c|}{18.13110 .0348420 .085322} \\
\hline 3 & 6 & 8 & & & \multicolumn{3}{|c|}{18.14260 .0181370 .077669} \\
\hline 4 & 0 & 08 & 5.6 & 2.2 & \multicolumn{3}{|c|}{$18.2184|0.002737| 0.025401$} \\
\hline 5 & 1 & 0. & 6.0 & 2.0084 & \multicolumn{3}{|c|}{18.24490 .0006070 .013080} \\
\hline 6 & 6. & 0. & 5. & 2.1 & \multicolumn{3}{|c|}{18.25640 .0000000 .005946} \\
\hline 7 & & & & & \multicolumn{3}{|c|}{18.25840 .0000000 .003333} \\
\hline 8 & & 0 & & & \multicolumn{3}{|c|}{18.26290 .0000000 .001526} \\
\hline 9 & & & & 2.1 & \multicolumn{3}{|c|}{18.26320 .0000000 .000879} \\
\hline 10 & & 0 & & 2. & \multicolumn{3}{|c|}{18.26390 .0000000 .000382} \\
\hline 11 & 8 & 0 . & 5 . & 2.1 & \multicolumn{3}{|c|}{18.26420 .0000000 .000223} \\
\hline 12 & 6. & 0. & & 2.1 & \multicolumn{3}{|c|}{18.26440 .0000000 .000096} \\
\hline 13 & 6.8535 & 0.5803 & 5.8511 & 2.1997 & \multicolumn{3}{|c|}{18.26440 .0000000 .000000} \\
\hline
\end{tabular}




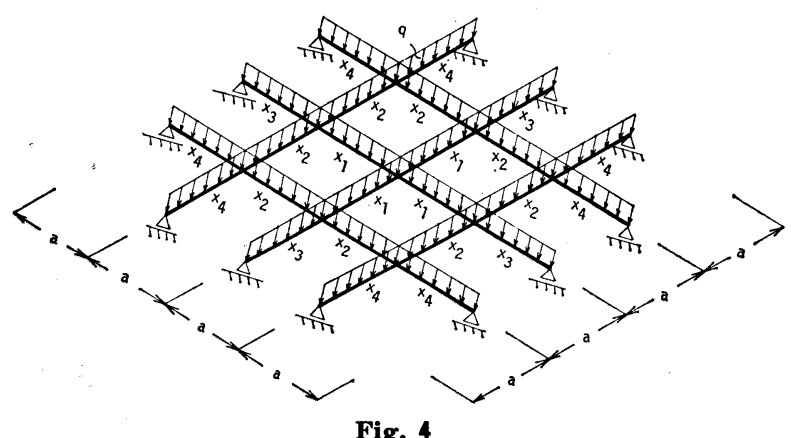

Fig. 4

差のため完全に収束させることは困難である。しかしな がら, 実用的見地からすれば重量の值においてほとんど 差がないことから考えて, この程度の繰り返し回数で得 られた結果を最適解としても十分差しつかえないものと 思われる。

\section{（2） 3 または 4 主桁，3 横桁をもつ単純格子桁}

最初に Fig. 5 に示す単純支持端（ねじりには抵抗す る) をもつ 3 主桁， 3 横桁の格子桁が等分布荷重 $q$ と 偏心集中荷重 $P$ を受ける場合を取り扱った。部材は全 部で 18 あるが, 対称性を考慮して独立な設計変数を 10 とした。主桁は箱型断面, 横桁は I 型断面を持つものと し，横桁のねじり抵抗は無視した。ここではこの種の格 子桁の一般的性質を知ることを目的とするため, 重量関 数は簡単化して次のように表わした。

$$
\begin{aligned}
W(\boldsymbol{x})= & c_{0}+a\left(2 X_{1}+2 X_{2}+2 X_{3}+2 X_{4}\right. \\
& +2 X_{5}+2 X_{6}+\alpha X_{7}+\alpha X_{8} \\
& \left.+2 \alpha X_{9}+2 \alpha X_{10}\right)
\end{aligned}
$$

ここに $c_{0}$ は任意の正の定数である。計算結果は

Table 3, 4, 5 に示す。Table 3 は $P=10 \times q a / 2$ の場
合について主桁のねじり抵抗の大小が設計変数の值 にどのように影響を与えるかを調べたものである。 この結果から主桁のねじり抵抗は横桁の端部の固定 作用のみに寄与するに過ぎなく，全体におよぼす影 響は非常に小さいことがわかり，これは前述した正 方形格子桁の結果と大きく相違するところである。

したがって同じ全塑性曲げモーメントを与える断面 では箱型断面より I 型断面の方が断面積が少ないの で，この種の格子桁では主桁もI 形断面にする方が より経済的であると推測される。

次に, Table 4 は主桁の全塑性ねじりモーメントの 全塑性曲げモーメントに対する比 $\beta$ が 0.55 の場合につ いて偏心集中荷重の大きさを変化させた時に最適設計断 面がどのように変化するかを調べたものであり， Table 5 は $P=10 \times q a / 2$ の場合について横桁間隔に対する主 桁間隔の比を変化させた時の影響を調べた.ものである。 これらの結果より, 最小重量設計においては偏心集中荷 重はそれが作用する主桁のみによって支持され，他の桁 は分布荷重のみに抵抗するに過ぎないことがわかる。し たがってこの種の格子栴の最小重量設計においては高次

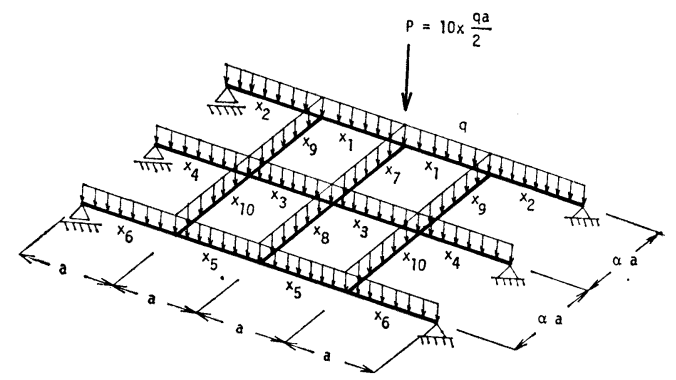

\begin{tabular}{|c|c|c|c|c|c|c|c|c|c|c|c|}
\hline \multirow{2}{*}{$\beta=T_{0} / M_{0}$} & \multicolumn{10}{|c|}{ Design Variables $\left(\times \mathrm{qa}^{2} / 2\right)$} & \multirow{2}{*}{$\begin{array}{l}\text { Weight } W-c_{0} \\
\left(\times \mathrm{qa}^{3} / 2\right)\end{array}$} \\
\hline & $X_{1}$ & $X_{2}$ & $X_{3}$ & $X_{4}$ & $X_{5}$ & $X_{6}$ & $X_{7}$ & $X_{8}$ & $X_{9}$ & $X_{10}$ & \\
\hline 0.05 & 15.667 & 9.5340 & 8.6694 & 6.5033 & 5.6640 & 4.2463 & 0.16991 & 0.17149 & 0.17038 & 0.16956 & 101.0228 \\
\hline 0.1 & 15.727 & 9.2963 & 8.5913 & 6.4443 & 5.6862 & 4.2677 & 0.16277 & 0.16708 & 0.16143 & 0.16751 & 101.0051 \\
\hline 0.3 & 16.001 & 9.5205 & 8.1228 & 6.0614 & 5.8772 & 4.4638 & 0.12500 & 0.12500 & 0.12500 & 0.15758 & 100.8751 \\
\hline 0.5 & 16.000 & 9.5070 & 8.0000 & 6.0000 & 6.0010 & 4.5156 & 0.12500 & 0.12500 & 0.12500 & 0.12500 & 100.7969 \\
\hline 0.8 & 16.000 & 9.5029 & 8.0000 & 6.0000 & 6.0005 & 4.5061 & 0.12500 & 0.12500 & 0.12500 & 0.12500 & 100.7689 \\
\hline 1.0 & 16.000 & 9.5017 & 8.0000 & 6.0000 & 6.0002 & 4.5038 & 0.12500 & 0.12500 & 0.12500 & 0.12500 & 100.7615 \\
\hline 1.15 & 16.000 & 9.5012 & 8.0000 & 6.0000 & 6.0000 & 4.5026 & 0.12500 & 0.12500 & 0.12500 & 0.12500 & 100.7577 \\
\hline
\end{tabular}

Fig. 5

Table 3 Minimum weight design for the grillage girder shown in Fig. 5 where $\alpha=1.0$ and $P=10 \times \mathrm{qa} / 2$

Table 4 Minimum weight design for the grillage girder shown in Fig. 5 where $\alpha=1.0$ and $\beta=0.55$

\begin{tabular}{c|c|c|c|c|c|c|c|c|c|c|c}
\hline \multirow{2}{*}{$\mathrm{qa} / 2: P$} & \multicolumn{10}{c|}{ Design Variables $\left(\times \mathbf{q a}^{2} / 2\right)$} & $X^{\text {Weight }} \begin{array}{l}W-c_{0} \\
\left(\times \mathbf{q a}^{3} / 2\right)\end{array}$ \\
\cline { 2 - 10 } & $X_{1}$ & $X_{2}$ & $X_{3}$ & $X_{4}$ & $X_{5}$ & $X_{6}$ & $X_{7}$ & $X_{8}$ & $X_{9}$ & $X_{10}$ & 70.802 \\
\hline $1: 0$ & 6.0000 & 4.5129 & 8.0000 & 6.0000 & 6.0000 & 4.5129 & 0.1250 & 0.1250 & 0.1250 & 0.1250 & 730 \\
$1: 1$ & 7.0000 & 5.0116 & 8.0000 & 6.0000 & 6.0000 & 4.5129 & 0.1250 & 0.1250 & 0.1250 & 0.1250 & 73.799 \\
$1: 3$ & 9.0000 & 6.0097 & 8.0000 & 6.0000 & 6.0000 & 4.5129 & 0.1250 & 0.1250 & 0.1250 & 0.1250 & 79.795 \\
$1: 10$ & 16.0000 & 9.5000 & 8.0000 & 6.0000 & 6.0000 & 4.5129 & 0.1250 & 0.1250 & 0.1250 & 0.1250 & 100.776 \\
$1: 50$ & 56.0000 & 29.5000 & 8.0000 & 6.0000 & 6.0000 & 4.5129 & 0.1250 & 0.1250 & 0.1250 & 0.1250 & 220.776 \\
$1: \infty$ & $1.0 \times \mathrm{Pa}$ & $0.5 \times \mathrm{Pa}$ & 0.0 & 0.0 & 0.0 & 0.0 & 0.0 & 0.0 & 0.0 & 0.0 & $3.0 \times \mathrm{Pa}$ \\
\hline
\end{tabular}


Table 5 Minimum weight design for the grillage girder shown in Fig. 5 where $P=10 \times \mathrm{qa} / 2$ and $\beta=0.55$

\begin{tabular}{|c|c|c|c|c|c|c|c|c|c|c|c|}
\hline \multirow{2}{*}{$\alpha$} & \multicolumn{10}{|c|}{ Design Variables $\left(\times \mathrm{qa}^{2} / 2\right)$} & \multirow{2}{*}{$\begin{array}{l}\text { Weight } W-c_{0} \\
\left(\times \mathbf{q a}^{3} / 2\right)\end{array}$} \\
\hline & $X_{1}$ & $X_{2}$ & $X_{3}$ & $X_{4}$ & $X_{5}$ & $X_{6}$ & $X_{7}$ & $X_{\varepsilon}$ & $X_{9}$ & $X_{10}$ & \\
\hline 0.4 & 14.800 & 8.6000 & 5.8463 & 4.3820 & 4.5537 & 3.4256 & 0.1250 & 0.1381 & 0.1250 & 0.1370 & 83.5301 \\
\hline 0.6 & 15.200 & 8.9000 & 6.4000 & 4.8000 & 5.2000 & 3.9149 & 0.1250 & 0.1250 & 0.1250 & 0.1250 & 89.2797 \\
\hline 0.8 & 15.600 & 9.2000 & 7.2000 & 5.4000 & 5.6000 & 4.2138 & 0.1250 & 0.1250 & 0.1250 & 0.1250 & 95.0276 \\
\hline 1.0 & 16.000 & 9.5000 & 8.0000 & 6.0000 & 6.0000 & 4.5129 & 0.1250 & 0.1250 & 0.1250 & 0.1250 & 100.7758 \\
\hline 1.2 & 16.400 & 9.8000 & 8.8000 & 6.6000 & 6.4000 & 4.8121 & 0.1250 & 0.1250 & 0.1250 & 0.1250 & 106.5242 \\
\hline 1.4 & 16.800 & 10.100 & 9.6000 & 7.2000 & 6.8000 & 5.1114 & 0.1250 & 0.1250 & 0.1250 & 0.1250 & 112.2728 \\
\hline 2.0 & 18.000 & 11.000 & 12.000 & 9.0000 & 8.0000 & 6.0097 & 0.1250 & 0.1250 & 0.1250 & 0.1250 & 129.5194 \\
\hline
\end{tabular}

Table 6 Minimum weight design for the grillage girder shown in Fig. 6 where $P=10 \times \mathrm{qa} / 2$ and $\beta=0.55$

\begin{tabular}{|c|c|c|c|c|c|c|c|c|c|c|c|c|c|c|c|}
\hline \multirow{2}{*}{$\alpha$} & \multicolumn{14}{|c|}{ Design Variables $\left(\times \mathrm{qa}^{2} / 2\right)$} & \multirow{2}{*}{$\begin{array}{c}\text { Weight } W-c_{0} \\
\quad\left(\times \mathbf{q a}^{3} / 2\right)\end{array}$} \\
\hline & $X_{1}$ & $X_{2}$ & $X_{3}$ & $X_{4}$ & $X_{5}$ & $X_{6}$ & $X_{7}$ & $X_{8}$ & $X_{9}$ & $X_{10}$ & $X_{11}$ & $X_{12}$ & $X_{13}$ & $X_{14}$ & \\
\hline 0.4 & 14.800 & 8.6000 & 5.6000 & 4.2000 & 5.8493 & 4.3818 & 4.5507 & 3.4258 & 0.1250 & 0.1250 & 0.1388 & 0.1250 & 0.1250 & 0.1367 & 103.280 \\
\hline 0.6 & 15.200 & 8.9000 & 6.4000 & 4.8000 & 6.4000 & 4.8000 & 5.2000 & 3.9149 & 0.1250 & 0.1250 & 0.1250 & 0.1250 & 0.1250 & 0.1250 & 111.905 \\
\hline 0.8 & 15.600 & 9.2000 & 7.2000 & 5.4000 & 7.2000 & 5.4000 & 5.6000 & 4.2138 & 0.1250 & 0.1250 & 0.1250 & 0.1250 & 0.1250 & 0.1250 & 120.528 \\
\hline 1.0 & 16.000 & 9.5000 & 8.0000 & 6.0000 & 8.0000 & 6.0000 & 6.0000 & 4.5129 & 0.1250 & 0.1250 & 0.1250 & 0.1250 & 0.1250 & 0.1250 & 129.151 \\
\hline 1.2 & 16.400 & 9.8000 & 8.8000 & 6.6000 & 8.8000 & 6.6000 & 6.4000 & 4.8121 & 0.1250 & 0.1250 & 0.1250 & 0.1250 & 0.1250 & 0.1250 & 137.774 \\
\hline 1.4 & 16.800 & 10.100 & 9.6000 & 7.2000 & 9.600 & 7.2000 & 6.8000 & 5.1114 & 0.1250 & 0.1250 & 0.1250 & 0.1250 & 0.1250 & 0.1250 & 146.398 \\
\hline 2.0 & 18.000 & 11.000 & 12.000 & 9.0000 & 12.000 & 9.0000 & 8.0000 & 6.0097 & 0.1250 & 0.1250 & 0.1250 & 0.1250 & 0.1250 & 0.1250 & 172.269 \\
\hline
\end{tabular}

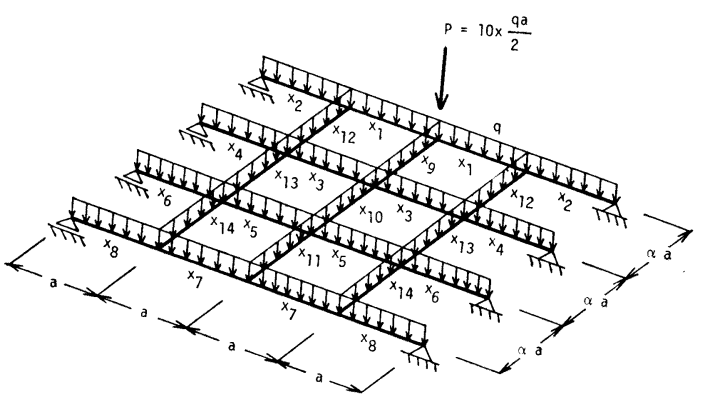

Fig. 6

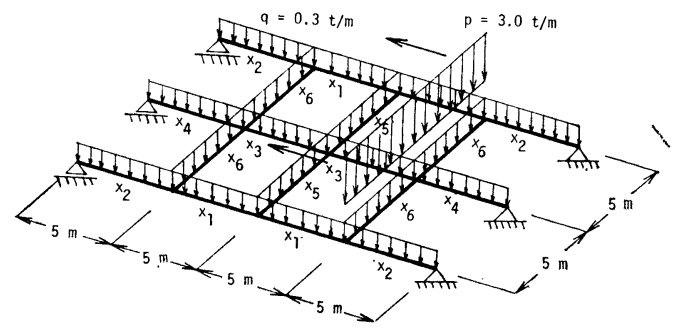

Fig. 7

の不静定構造としての複雑な荷重分配作用を考える必要 はなく, 主桁はスパン $4 a$ の単純桁, 横桁はスパン $\alpha a$ の 2 径間連続桁として設計すれば十分であるものと推測 できる。

次に, Table 6 は Fig. 6 に示した 4 主桁, 3 横桁 の格子桁に対して, 重量関数は $W(\boldsymbol{x})=c_{0}+a\left(2 X_{1}+\right.$ $2 X_{2}+2 X_{3}+2 X_{4}+2 X_{5}+2 X_{6}+2 X_{7}+2 X_{8}+\alpha X_{9}+\alpha$. $\left.X_{10}+\alpha X_{11}+2 \alpha X_{12}+2 \alpha X_{13}+2 \alpha X_{14}\right)$ と仮定し, 3 主 桁の場合と同じ条件の下に計算した結果を示したもので ある。この結果は 3 主桁の場合と全く類似した傾向を示 していることがわかる。
最後の計算例はもっとも実際的な問題として Fig. 7 に示す等分布荷重 $q=0.3 \mathrm{t} / \mathrm{m}$ と移動線荷重 $p=3.0 \mathrm{t} / \mathrm{m}$ を受ける単純格子桁をとり上げた。主桁は $\beta=0.55$ な る箱形断面とし, 横桁は I 形断面とし $\beta=0$ と仮定し た。各部材の断面積と塑性断面係数との間の関係は, 式 (3.1) および式 (3.2) の折線近似を用い，断面積と部材 長の積和によって重量関数を表わした。計算に当って は, 最初に重量関数を適当に仮定して最適解を求め, こ れを初期值として式 (3.1) および式 (3.2) により重量 関数を修正して繰り返した。こうして求めた最適解は

$X_{1}=58.362 \mathrm{tm}, X_{2}=52.736 \mathrm{tm}, X_{3}=108.282 \mathrm{tm}$,

$X_{4}=63.281 \mathrm{tm}, X_{5}=5.156 \mathrm{tm}, X_{6}=5.156 \mathrm{tm}$ となり*,この場合も前述した一般的傾向と一致した結 果を示している。なお, 移動線荷重の取り扱いについて は, 横桁上に載っていない場合は挺子の法則によって隣 接する横桁に分配されるものと仮定した。すると本問題 に対しては対称条件により, 線荷重が中央横桁上にある 場合と他の一つの横桁上にある場合の二つ荷重状態を考 慮した問題としての取り扱いで十分となる。なぜなら ば,こうして得られた設計はこの両荷重状態に対してそ れぞれ静的許容かつ安全な応力場を持つことができ，い まこれらの応力場を $\left\{\boldsymbol{y}_{1}\right\}+\left\{\boldsymbol{y}_{0}\right\}, \quad\left\{\boldsymbol{y}_{2}\right\}+\left\{\boldsymbol{y}_{0}\right\}, こ こ に$ $\left\{\boldsymbol{y}_{0}\right\}$ は固定分布荷重に対する応力場, と定義すれば, 線荷重が一つの横桁から $\lambda a$ なる距離にある場合に対し て応力場 $(1-\lambda)\left\{\boldsymbol{y}_{1}\right\}+\lambda\left\{\boldsymbol{y}_{2}\right\}+\left\{\boldsymbol{y}_{0}\right\}$, ただし $0 \leq \lambda \leq 1$, は静的許容であり, 一方降伏条件式を犯さない領域は凸 領域であるから，これはまた安全でもある。したがって

*この問題の計算時間は倍精度演算にて約 24 分であった。な お使用計算機は大阪市立大学計算センター所有の FACOM 270-30 である。 
極限強度解析法の下界定理よりここで得られた設計は横 桁上にない線荷重に対しても安全であり, よって求むべ き最小重量設計である。

\section{5. 結 論}

本論文において集中荷重, 等分布荷重およびそれらの 変動荷重を受ける格子桁の最小重量設計問題の一つの解 析法を示した。すなわち最小重量設計問題を極限強度解 析法の下界定理に基づく極值問題として取り扱い，数值 計算には凸計画の問題の計算法である J.E. Kelley の Cutting Plane Methodを利用した。

本文で示した解析法を用いて橋梁などに見られる単純 格子桁の最小重量設計を行なった結果, 最適部材断面を 有する格子桁では主桁のねじり抵抗は横桁の端部の固定 作用に影響するのみであり, 全体に与える影響は非常に 少ない。したがって実用的には横桁は主桁で支えられた 連続桁として設計し，主桁は直接に受ける荷重と横桁の 反力が作用する単純桁として設計すれば十分であること が推測できた。

最後に, 本論文の図表の作成にあたっては大阪市立大 学大学院川村修一君の援助を受けたことを付記します。

\section{参 考 文 献}

1) Foulkes, J. : Minimum Weight Design and the Theory of Plastic Collapse, Quart. Appl. Math., 10. 347 358 (1953)

2) Foulkes, J. : Minimum Weight Design of Structural Frames, Proc. Roy. Soc. (London), A 223, 482 494 (1954)

3) Livesley, R.: The Automatic Design of Structural Frames, Quart. J. Mech. Appl. Math., Vol. 9, 257 278 (1956)

4) Tanaka, H. : Automatic Analysis and Design of Plastic Frames, Report of the Institute of Industrial Science, University of Tokyo, Vol. 12, No. 3, Sep. (1962)

5) Toakley, A.R. : Some Computational Aspects of Optimum Rigid-Plastic Design, Int. J. Mech. Sci., Vol. 10, 531 537 (1968)

6) Heymann, J. : The Limit Design of a Transversley Loaded Square Grid, J. Appl. Mech. 19, 153 158 (1952)

7） 米沢 博: 格子桁構造の極限荷重および最小重量設計に 関する一研究, 土木学会論文集第 67 号, $11 \sim 18$, 昭和 35 年 3 月

8) Kelley, J.E., Jr. : The Cutting Plane Method for Solving Convex Programs, J. Soc. Indust. Appl. Math. Vol. 8, No. 4, 703 712 (1960)

9) 森口繁一・宮下藤太郎: 線型計画法, 岩波講座 現在応用 数学, B. 12-6, 岩波書店

10) Gass, S.I. (小山訳) : 線型計画法, 好学社

11) Nadai, A. : Theory of Flow and Fracture of Solids, Vol. 1, McGRAW-HILL, 490 526 (1950)

\section{付録一1 I 型および箱型断面における全塑性曲 げモーメントに対する全塑性ねじりモ ーメントの比}

Fig. 1 に示す I 型断面の全塑性曲げモーメント $M_{0}$ は

$$
M_{0}=\sigma_{0}\left\{17 t^{2}\left(70 t_{w}-t\right)+0.25 t_{w}\left(70 t_{w}-2 t\right)^{2}\right\}
$$

ここに $\sigma_{0}$ は一軸引張 (圧縮) 降伏応力である。一方， 全塑性ねじりモーメントは A. Nadai の Sand heap Analogy ${ }^{11)}$ を利用することによって計算できる。すな わち I 型断面に対する Sand heap を描けば Fig. 8 の ようになり，この Sand heap の体積の 2 倍が全塑性ね ビりモーメント $T_{0}$ に等しいことより,

$$
T_{0} \fallingdotseq \tau_{0}\left\{17 t^{3}+0.5 t_{w}{ }^{2}\left(70 t_{w}-2 t\right)\right\} \cdots \cdots \cdots(\mathrm{A}-2)
$$

ここに $\tau_{0}$ はせん断降伏応力であり, Von Mises の 降伏条件式にしたがえば， $\tau_{0}=\sigma_{0} / \sqrt{3}$ である。

次に, 箱型断面の全塑性曲げモーメントは

$$
M_{0}=\sigma_{0}\left\{2 t\left(16 t-t_{w}\right)\left(70 t_{w}-t\right)+2450 t_{w}{ }^{3}\right\}
$$

\section{(A-3)}

全塑性ねじりモーメントは Fig. 9 の Sand heap か ら計算することができ, $t \geq t_{w}$ に対しては,

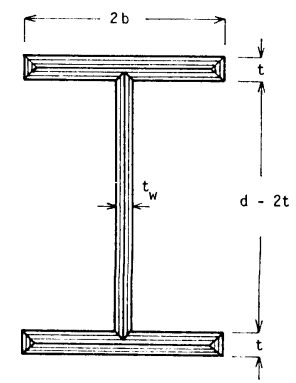

Sand heap for I cross section

Fig. 8

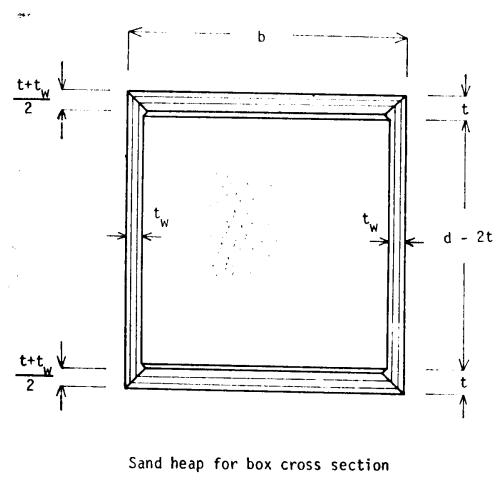

Fig. 9 


$$
\begin{aligned}
& T_{0} \fallingdotseq 2 \tau_{0}\left\{t_{w}{ }^{2}\left(2208 t-68 t_{w}\right)+\left(t-t_{w}\right)^{2}\left(16 t-t_{w}\right)\right\} \\
& \cdot\left(\mathrm{A}-4^{\prime}\right) \\
& t_{w}>t \text { に対しては, } \\
& T_{0} \doteqdot 2 \tau_{0}\left\{t^{2}\left(2170 t_{w}-30 t\right)+\left(t_{w}-t\right)^{2}\left(35 t_{w}-t\right)\right\} \\
& \left(\mathrm{A}-4^{\prime \prime}\right)
\end{aligned}
$$

したがって，Fig. 1 の太線で示した曲線上のいくつ かの断面について全塑性曲げモーメントに対する全塑性 ねじりモーメントの比 $\beta$ を式 $(\mathrm{A}-1) \sim$ 式 $\left(\mathrm{A}-4^{\prime \prime}\right)$ を用 いて計算すれば Table 7 のようになり，I 型断面では $\beta=0.0126 \sim 0.0138$, 箱型断面では $\beta=0.467 \sim 0.549$ で あり，二，三の断面を除けばほとんど一定值を示してい

Table 7 Values of $\beta$ of the $I$ cross section shown in Fig. 1

\begin{tabular}{l|l|r|r|r|r}
\hline$t_{w}(\mathrm{~cm})$ & $t(\mathrm{~cm})$ & $A\left(\mathrm{~cm}^{2}\right)$ & $\begin{array}{r}M_{0} / \sigma_{0} \\
\left(\mathrm{~cm}^{3}\right)\end{array}$ & $\begin{array}{r}T_{0} / \tau_{0} \\
\left(\mathrm{~cm}^{3}\right)\end{array}$ & $\beta=T_{0} / M_{0}$ \\
\hline 0.45 & 0.424 & 19.9 & 203 & 4.4 & 0.0126 \\
0.50 & 0.518 & 26.1 & 306 & 6.7 & 0.0126 \\
0.60 & 0.458 & 31.8 & 407 & 9.1 & 0.0129 \\
0.65 & 0.606 & 41.3 & 608 & 13.3 & 0.0126 \\
0.70 & 0.700 & 50.0 & 811 & 17.7 & 0.0126 \\
0.75 & 0.762 & 58.0 & 1013 & 22.1 & 0.0126 \\
0.85 & 0.891 & 76.1 & 1522 & 33.2 & 0.0126 \\
0.95 & 0.950 & 92.1 & 2027 & 44.2 & 0.0126 \\
1.00 & 1.073 & 107.0 & 2536 & 55.4 & 0.0126 \\
1.10 & 1.063 & 120.8 & 3044 & 66.4 & 0.0126 \\
1.20 & 1.192 & 146.3 & 4058 & 88.4 & 0.0126 \\
1.25 & 1.235 & 158.2 & 4563 & 99.4 & 0.0126 \\
1.30 & 1.269 & 169.8 & 5073 & 110.6 & 0.0126 \\
1.35 & 1.292 & 180.9 & 5577 & 121.6 & 0.0126 \\
1.40 & 1.424 & 202.2 & 6593 & 143.7 & 0.0126 \\
1.50 & 1.427 & 222.5 & 7607 & 165.9 & 0.0126 \\
1.55 & 1.517 & 241.8 & 8621 & 187.9 & 0.0126 \\
1.60 & 1.593 & 260.4 & 9636 & 210.0 & 0.0126 \\
1.60 & 1.834 & 287.8 & 11155 & 245.9 & 0.0127 \\
1.60 & 2.048 & 315.3 & 12674 & 286.7 & 0.0131 \\
1.60 & 2.361 & 361.3 & 15201 & 364.2 & 0.0138 \\
\hline
\end{tabular}

Table 8 Values of $\beta$ of the box cross section shown in Fig. 1

\begin{tabular}{c|c|r|r|r|r}
\hline$t_{w}(\mathrm{~cm})$ & $t(\mathrm{~cm})$ & $A\left(\mathrm{~cm}^{2}\right)$ & $\begin{array}{r}M_{0} / \sigma_{0} \\
\left(\mathrm{~cm}^{3}\right)\end{array}$ & $\begin{array}{r}T_{0} / \tau_{0} \\
\left(\mathrm{~cm}^{3}\right)\end{array}$ & $\beta=T_{0} / M_{0}$ \\
\hline 0.50 & 0.434 & 46.2 & 500 & 233 & 0.467 \\
0.50 & 0.539 & 52.5 & 608 & 334 & 0.549 \\
0.55 & 0.509 & 57.8 & 701 & 353 & 0.503 \\
0.60 & 0.548 & 68.3 & 900 & 446 & 0.495 \\
0.70 & 0.675 & 95.9 & 1499 & 789 & 0.526 \\
0.75 & 0.788 & 116.1 & 2000 & 1097 & 0.548 \\
0.80 & 0.866 & 134.8 & 2501 & 1373 & 0.549 \\
0.85 & 0.920 & 152.2 & 3000 & 1647 & 0.549 \\
0.90 & 0.958 & 168.7 & 3501 & 1921 & 0.549 \\
0.95 & 0.982 & 184.3 & 4000 & 2192 & 0.548 \\
1.00 & 0.995 & 199.4 & 4499 & 2447 & 0.544 \\
1.05 & 1.105 & 227.9 & 5497 & 3015 & 0.549 \\
1.10 & 1.097 & 241.6 & 6000 & 3271 & 0.545 \\
1.15 & 1.172 & 267.7 & 7000 & 3832 & 0.548 \\
1.20 & 1.231 & 292.6 & 8003 & 4384 & 0.548 \\
1.25 & 1.276 & 316.5 & 9003 & 4930 & 0.548 \\
1.30 & 1.310 & 339.6 & 10003 & 5472 & 0.547 \\
1.35 & 1.459 & 383.5 & 11999 & 6587 & 0.549 \\
1.40 & 1.470 & 404.5 & 13000 & 7130 & 0.548 \\
1.45 & 1.528 & 435.0 & 14495 & 7952 & 0.549 \\
\hline & & & & &
\end{tabular}

る。

\section{付録一2 Cutting Plane Method for Convex Programming ${ }^{\text {s) }}$}

J.E. Kelley 氏は非線型拘束 $G(\boldsymbol{x}) \leq 0$ の下で線型関 数

$$
f=\sum_{i=1}^{n} c_{i} x_{i}
$$

を最小にする問題を考えた。ここに $G(\boldsymbol{x})$ は次の条件 を満足するものとする。(1) $G(\boldsymbol{x})$ は連続な凸関数であ る, (2) $G(\boldsymbol{x})$ は $n$ 次元多面体の内部 $S=\{\boldsymbol{x} \mid \boldsymbol{A} \cdot \boldsymbol{x} \geq$ $\boldsymbol{b}\}$, ただし $\boldsymbol{A}$ は $m \times n$ のマトリックス, $\boldsymbol{x}$ は $n \times 1$ の 変数べクトル，において定義されている，(3) $S$ におけ る任意の点 $\boldsymbol{t}$ において, $G(\boldsymbol{x})$ のグラフに対する支持 超平面* $y=p(\boldsymbol{x} ; \boldsymbol{t})$ が存在し, $\|\boldsymbol{\nabla} p(\boldsymbol{x} ; \boldsymbol{t})\|$ は有限值 をとる。

いま, $R=\{\boldsymbol{x} \mid G(\boldsymbol{x}) \leq 0\}, R \subset S$ とすれば， $S-R$ に ある任意の点 $\boldsymbol{t}$ に扔いて $G(\boldsymbol{x})$ に対する支持超平面は

$$
p(\boldsymbol{x} ; \boldsymbol{t})=G(\boldsymbol{t})+\boldsymbol{\nabla} p(\boldsymbol{x} ; \boldsymbol{t})(\boldsymbol{x} ; \boldsymbol{t})=y \cdots \cdots(\mathrm{A}-6)
$$

と表わされる。 $G(\boldsymbol{x})$ は凸関数であるから， $\boldsymbol{x} \in S$ にお いて $p(\boldsymbol{x} ; \boldsymbol{t}) \leq G(\boldsymbol{x})$ であり, $\boldsymbol{x} \in R$ に执いて $p(\boldsymbol{x} ; \boldsymbol{t})$ $\leq 0$ となる。したがって点 $\boldsymbol{t}$ と $R$ は超平面 $p(\boldsymbol{x} ; \boldsymbol{t})$ $=0$ に対して互いに反対側に位置する。さて, $S_{0}=S$ と し， $S_{0}$ において式 (A-5) の目的関数 $f$ の最小にする 解を $\boldsymbol{t}_{0}$ (一般に $\boldsymbol{t}_{0}$ は $S_{0}-R$ に存在する, むしそうで なければ $\boldsymbol{t}_{0}$ は求める解となる) とする。さらに,

$$
\begin{aligned}
& S_{1}=S_{0} \cap\left\{\boldsymbol{x} \mid p\left(\boldsymbol{x} ; \boldsymbol{t}_{0}\right) \leq 0\right\} \\
& S_{2}=S_{1} \cap\left\{\boldsymbol{x} \mid p\left(\boldsymbol{x} ; \boldsymbol{t}_{1}\right) \leq 0\right\} \\
& S_{k}=S_{k-1} \cap\left\{\boldsymbol{x} \mid p\left(\boldsymbol{x} ; \boldsymbol{t}_{k-1}\right) \leq 0\right\}
\end{aligned}
$$

と置き, $\boldsymbol{t}_{k}$ を $S_{k}$ 内で目的関数 $f=\boldsymbol{c x}$ を最小にする 点とし, $f_{k}=\boldsymbol{c t}{ }_{k}$ とすれば,

$$
S_{k} \subset S_{k-1} \subset \cdots \cdots \subset S_{1} \subset S_{0},
$$

そして,

$$
f_{k} \geq f_{k-1} \geq \cdots \cdots \geq f_{1} \geq f_{0}
$$

となり, 列 $\left\{\boldsymbol{t}_{k}\right\},\left\{f_{k}\right\}$ が求まる。それゆえ $\left\{\boldsymbol{t}_{k}\right\}$ が $R$ の内部の一点 $\tau$ に収束する部分列を含むかどうか調べ なければならない。もしこのような収束する部分列が存 在するならば，ここで示した計算方法によって得られた 単調に増加する列 $\left\{f_{k}\right\}$ は $f(=\min .\{\boldsymbol{c x} \mid \boldsymbol{x} \in R\})$ に収 束し, $\boldsymbol{\tau}$ は求めるべき最適解となる。 $\left\{\boldsymbol{t}_{k}\right\}$ が $\boldsymbol{\tau}$ に収束 する部分列を含むことは次のように証明できる。もし $\boldsymbol{t}_{k}$ が $S_{k}$ において $\boldsymbol{c x}$ を最小にする点であるならば,

$$
G\left(\boldsymbol{t}_{i}\right)+\boldsymbol{\nabla} p\left(\boldsymbol{t}_{k} ; \boldsymbol{t}_{i}\right)\left(\boldsymbol{t}_{k}-\boldsymbol{t}_{i}\right) \leq 0(0 \leq i \leq k-1)
$$

\footnotetext{
$* n$ 次元空間における凸体 $Q$ に対して, $Q$ の境界とは共通 点をもつが， $Q$ の内部とは共通点をもたない平面を支持超 平面 (Supporting hyperplane) という。
} 
を満足しなければならない。もし $\left\{\boldsymbol{t}_{k}\right\}$ が $R$ の内部の 一点に収束する部分列を持つならば, $\left\{G\left(\boldsymbol{t}_{k}\right)\right\}$ はゼロに 収束する部分列を持た韹ばならない。もし求めるべき収 束が起こらないとするならば, $k$ に関係なく

$$
r \leq G\left(\boldsymbol{t}_{i}\right) \leq \boldsymbol{\nabla} p\left(\boldsymbol{t}_{k} ; \boldsymbol{t}_{\boldsymbol{i}}\right)\left(\boldsymbol{t}_{\boldsymbol{i}}-\boldsymbol{t}_{\boldsymbol{k}}\right) \leq K\left\|\boldsymbol{t}_{\boldsymbol{i}}-\boldsymbol{t}_{k}\right\|
$$

なる $r(>0)$ が存在する。ここに $K$ はある有限な正の 定数である。それゆえ任意の指数 (index) の列 $\left\{k_{p}\right\}$ に 対して

$$
\left\|\boldsymbol{t}_{k q}-\boldsymbol{t}_{k p}\right\| \geq r / K(q<p)
$$

となり，したがって列 $\left\{\boldsymbol{t}_{\boldsymbol{k}}\right\}$ はコーシーの部分列をもた ない。しかしながら $S$ は，連続する実数からなる集合

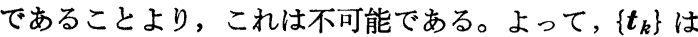
$S$ 内の一点 $\boldsymbol{\tau}$ に収束する部分列を持ち, $\left\{G\left(\boldsymbol{t}_{k}\right)\right\}$ はゼ 口に収束するから $\tau$ は $R$ 内になければならない。 次に，実際の計算に際しては，もし $G(\boldsymbol{x})$ がいたる ところで微分可能であるならば, $\boldsymbol{\nabla} p\left(\boldsymbol{x} ; \boldsymbol{t}_{k}\right)=\boldsymbol{\nabla} G\left(\boldsymbol{t}_{k}\right)$ となり, $\boldsymbol{t}_{j}(0 \leq j \leq k-1)$ は次の線型計画の 問題を解 くことによって求められる。

$$
\begin{aligned}
& \boldsymbol{A} \cdot \boldsymbol{x} \geq \boldsymbol{b}, \\
& -\boldsymbol{\nabla} p\left(\boldsymbol{x} ; \boldsymbol{t}_{j}\right) \cdot \boldsymbol{x} \geq G\left(\boldsymbol{t}_{j}\right)-\boldsymbol{\nabla} p\left(\boldsymbol{x} ; \boldsymbol{t}_{j}\right) \cdot \boldsymbol{t}_{j} \\
& (0 \leq j \leq k-1),
\end{aligned}
$$$$
f=\boldsymbol{c} \cdot \boldsymbol{x}=\operatorname{minimum}
$$

さて，上述の議論にしたがって本論文式（10）に対す る Cutting Plane を求めれば,

$$
\begin{aligned}
G(\boldsymbol{x})= & \sqrt{\left(M_{i h^{\prime}}-X_{i h}\right)^{2}+\frac{1}{\beta_{i h^{2}}}\left(T_{i h^{\prime}}-\beta_{i h} X_{i h}\right)^{2}} \\
& -X_{i h} .
\end{aligned}
$$

$\boldsymbol{t}_{j}=\left(t_{1}, t_{2}, t_{3}\right)$ とすれば

$$
\begin{gathered}
\boldsymbol{\nabla} p\left(\boldsymbol{x} ; \boldsymbol{t}_{j}\right)=\frac{1}{\sqrt{\left(t_{1}-t_{3}\right)^{2}+\frac{1}{\beta_{i h}{ }^{2}}\left(t_{2}-\beta_{i h} t_{3}\right)^{2}}} \\
\cdot\left[\left(t_{1}-t_{3}\right), \frac{1}{\beta_{i h}{ }^{2}}\left(t_{2}-\beta_{i h} t_{3}\right),\left\{-t_{1}-\frac{t_{2}}{\beta_{i h}}\right.\right. \\
\left.+2 t_{3}-\sqrt{\left.\left(t_{1}-t_{3}\right)^{2}+\frac{1}{\beta_{i h}{ }^{2}}\left(t_{2}-\beta_{i h} t_{3}\right)^{2}\right\}}\right]
\end{gathered}
$$

式 (A-7) より, $G\left(\boldsymbol{t}_{j}\right)+\boldsymbol{\nabla} p\left(\boldsymbol{x} ; \boldsymbol{t}_{j}\right)\left(\boldsymbol{x}-\boldsymbol{t}_{j}\right) \leq 0$ 上 っ

$$
\left(t_{1}-t_{3}\right) M_{i h^{\prime}}+\frac{t_{2}-\beta_{i h} t_{3}}{\beta_{i h^{2}}{ }^{2}} T_{i h^{\prime}}
$$

$$
\begin{aligned}
& -\left\{\sqrt{\left(t_{1}-t_{3}\right)^{2}+\frac{1}{\beta_{i h}{ }^{2}}\left(t_{2}-\beta_{i h} t_{3}\right)^{2}}\right. \\
& \left.+t_{1}-t_{3}+\frac{t_{2}-\beta_{i h} t_{3}}{\beta_{i h}}\right\} X_{i h} \leq 0 \cdots \cdots
\end{aligned}
$$

また，式（12）に対しては

$$
\begin{aligned}
G(\boldsymbol{x})= & \sqrt{\left(M_{\text {max }}^{\prime}-X_{i h}\right)^{2}+\frac{1}{\beta_{i h}{ }^{2}}\left(T_{i h^{\prime}}-\beta_{i h} X_{i h}\right)^{2}} \\
& -X_{i h},
\end{aligned}
$$

ここに

$$
\begin{aligned}
M_{\text {max }}^{\prime}= & \frac{q_{i h}}{8} \Lambda_{i h^{2}}+\frac{1}{2}\left(M_{i h^{\prime}}+M_{h i^{\prime}}\right) \\
& +\frac{1}{2 q_{i h} \Lambda_{i h^{2}}{ }^{2}}\left(M_{i h^{\prime}}-M_{h i^{\prime}}\right)^{2} \geq X_{i h} .
\end{aligned}
$$

$\boldsymbol{t}_{j}=\left(t_{1}, t_{1}{ }^{\prime}, t_{2}, t_{3}\right)$ とすれば

$$
\begin{array}{r}
\nabla p\left(\boldsymbol{x} ; \boldsymbol{t}_{j}\right)=\frac{1}{\sqrt{\left(t_{0}-t_{3}\right)^{2}+\frac{1}{\beta_{i h^{2}}}\left(t_{2}-\beta_{i h} t_{3}\right)^{2}}} \\
\cdot\left[\frac{1}{2}\left(t_{0}-t_{3}\right)\left\{1+\frac{2}{q_{i h} \Lambda_{i h}{ }^{2}}\left(t_{1}-t_{1}{ }^{\prime}\right)\right\},\right. \\
\frac{1}{2}\left(t_{0}-t_{3}\right)\left\{1-\frac{2}{q_{i h} \Lambda_{i h^{2}}}\left(t_{1}-t_{1}{ }^{\prime}\right)\right\}, \\
\frac{1}{\beta_{i h}{ }^{2}}\left(t_{2}-\beta_{i h} t_{3}\right),-t_{0}+2 t_{3}-\frac{t_{2}}{\beta_{i h}} \\
\left.-\sqrt{\left(t_{0}-t_{3}\right)^{2}+\frac{1}{\beta_{i h}{ }^{2}}\left(t_{2}-\beta_{i h} t_{3}\right)^{2}}\right] .
\end{array}
$$

ゆえに，

$$
\begin{aligned}
& \left\{1+\frac{2}{q_{i h} \Lambda_{i h}{ }^{2}}\left(t_{1}-t_{1}{ }^{\prime}\right)\right\} M_{i h^{\prime}}+\left\{1-\frac{2}{q_{i h} \Lambda_{i h}{ }^{2}}\right. \\
& \left.\cdot\left(t_{1}-t_{1}^{\prime}\right)\right\} M_{h i}{ }^{\prime}+\frac{2\left(t_{2}-\beta_{i h} t_{3}\right)}{\beta_{i h^{2}\left(t_{0}-t_{3}\right)}} T_{i h^{\prime}} \\
& -2\left\{1+\frac{t_{2}-\beta_{i h} t_{3}}{\beta_{i h}\left(t_{0}-t_{3}\right)}+\sqrt{1+\frac{1}{\beta_{i h^{2}}}\left(\frac{t_{2}-\beta_{i h} t_{3}}{t_{0}-t_{3}}\right)^{2}}\right\} \\
& \cdot X_{i h}+\frac{q_{i h} \Lambda_{i h^{2}}}{4}-\frac{1}{q_{i h} \Lambda_{i h}{ }^{2}}\left(t_{1}-t_{1}^{\prime}\right)^{2} \leq 0
\end{aligned}
$$

ここに

$$
\begin{aligned}
t_{0}= & \frac{q_{i h} \Lambda_{i h^{2}}{ }^{2}}{8}+\frac{1}{2}\left(t_{1}+t_{1}^{\prime}\right)+\frac{1}{2 q_{i h} \Lambda_{i h^{2}}{ }^{2}} \\
& \cdot\left(t_{1}-t_{1}\right)^{2} \geq t_{3} .
\end{aligned}
$$

(1971.3.24 • 受付) 